\title{
Schism, syncretism and politics: Derived and implied social model in the self-definition of early Christian orthodoxy
}

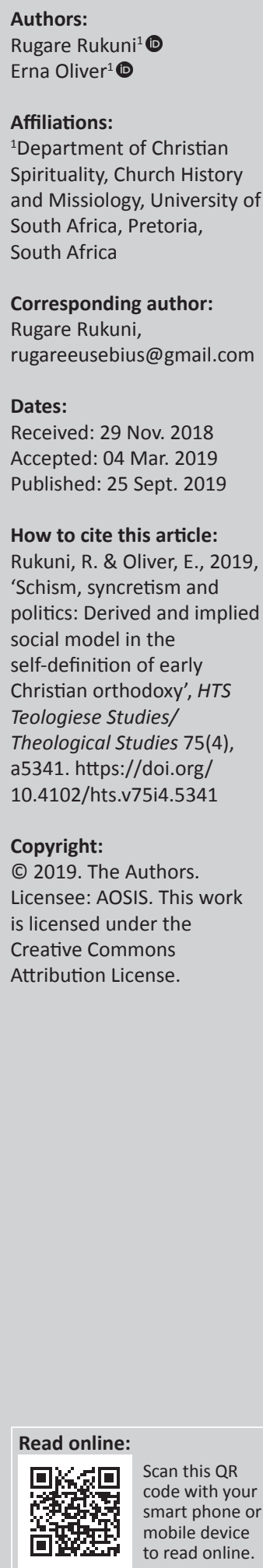

The first 400 years of Christianity posed an intricate scenario of social dynamics. The interplay of these social dynamics or catalysts analogous to time perceivably conceived the politicalreligious establishment that then forged orthodoxy. The resultant continuum that was consequent of the imperial religious-political merger upon the following eras further established a formative impact of these catalysts. As a revisionist analysis of the era leading up to the Constantinian turn, and a parallel comparison between preceding and following eras, this research proposes an alternate construction to the narrative of Early Christianity orthodoxy. The preceding position derives from the attempt at the development of a modular theory through which Christianity can be analysed. Through document analysis, a literature review was accomplished. The development of early Christianity from inception to $400 \mathrm{CE}$ when deduced against enculturating influences implies a sociological study. From the three perceived phases that Christianity went through, Jewish-Christian schism, Hellenism and then imperial interventional politics, implications can be made upon latter eras and derivations can be deduced from earlier eras. Significantly, there seems to have been a resurgent theme in the person of religious-political institutions that consolidated their positions. The synergy and inevitability of the process that preceded the first ecumenical council are confirmed in both a positive and negative substantiation of the proposed model. The emergent episcopal leadership in Christianity and its consolidation averse to the political dynamics of imperial Rome implied a composite significance of all factors. Similarly, the intransigent nature of certain African Christian elements argues for the inevitability of cultural enculturation as precedent to political definition in the formation of a universal orthodoxy.

Keyword: Church history; Jewish-Christian schism; Hellenism; Imperial orthodoxy; Politics; Enculturation; Self-definition; Social model.

\section{Introduction: Schismatic and cultic formation of orthodoxy}

The dominance of imperial Christianity at the turn of the 4th century is an established factor. Characterised by imperial interpositions that halted persecutions and a policy of largesse upon clerics, this feature of 4th-century Christianity was definitive (Barnes 2011:133; cf. Leithart 2010; Van Dam 2011). The preceding narrative is the entrenched theory regarding the entrance of the Emperor Constantine and its resultant orthodoxy as seen at the $325 \mathrm{CE}$ Council of Nicaea. This implies the paramount significance of the agency of the imperial political feature in the development of an orthodoxy that would become universal.

An alternative narrative can be deduced, however, regarding composite definitive factors in Christianity that caused a trajectory that oversaw the orthodoxy that emerged in this era. Another approach would be a deduction concerning the orthodoxy that emerged as a consolidation of preceding events. From the 1st to the 3rd century CE prior to the rise of Constantine, Christianity went through a tripartite definitive process. The 4th-century orthodoxy, a derivate of imperially backed councils, was conflation of an ideology of homogeneous practice amongst Hellenised Christians, who abdicated themselves from Judaic elements of their faith (Roldanus 2006).

The inception of Christianity was defined by schismatic dynamics in the 1st century CE, that is, the Jewish-Christian schism (Boyarin 2010:3). Subsequently, in a tone of apology, Christianity endearingly was redefined as a philosophy, thereby positioning itself as a derivate of Hellenic 
impressionism (Justin Address to Antoninus Pius First Apology 67; Schaff 1885a:290; cf. Drodge 2012:231). Perceivably in a cultic manner paralleling Jewish sects, Christian schismatics came into play as there was a multi-grouped endeavour for homogeneity (cf. Meissner 2000:66). The definitive nature of the heretical-orthodoxy cliques within Christianity implied a turf of philosophy against philosophy as evidenced in the ensuing controversies that incited the conciliar trajectory of the 3 rd and 4 th centuries.

\section{Method and design}

Document analysis was the main methodology. Composite to document analysis was cultural historiography that emphasises the multi-layered cultural detail in the narrative (Danto 2008:17). Most significantly there was an inference and deduction of sociological models congruent to the nature of the investigation. Although the study is historical, an approach was adopted that was akin to sociology of religion through derivations (cf. Grabbe 2007:119). The design and layout follow a blend of both topic and analysis.

\section{Antithesis derived synthesis}

There seems to be a substantial argument for mushrooming heresy as the impetus for the corresponding delineation of boundaries of orthodoxy. Deductively, despite the radical nature of Marcionite anti-Judaism and its invective approach, it would subsequently be composite to Christian orthodoxy (Nickelsburg 2003:195). Although this was perceivably reflective of apparent hostility to Judaism, correspondingly Christianity would then be characterised by an entrenched separation from Judaism and a systematic embrace of Hellenic philosophy. The resentment of the imperial establishment consequent of the early persecution had derailed the new modus in Christianity of kinship with Roman tradition. Christianity philosophised painstakingly sought redefinition as a religio licita [approved religion].

The preceding observation regarding orthodoxy as a synthesis derived from the convolution of heresy and imposed homogeneity provokes an enquiry. Rightly so the question can be posed: had there not been a Marcionite composition of Pauline works, would there have been an ecclesiastical initiative with regard to canon (cf. Gamble 2012:197)? Dually, the stance against the Nag Hammadi codices as divergent elements to the organising theology deciphered in books associated with apostolic tradition and authorship can be argued to be a resultant afterthought.

The Nag Hammadi library implies a diversity of views in the early church. Problematically, other archaeological finds serve to entrench the idea, for example, Manichaean religion has been further unravelled because of the Manichean library of Medinet Madi, Turfan, Oasis of Dakhleh and the Cologne Mani codex (Markschies 2003:59). When considered composite to hierarchical monarchical episcopate, the turbulent wave of schismatic and cultic activity characterising early Christianity induced a trajectory for an ecumenical orthodoxy.

Imperial interposition consolidated this definitive era in Christian history through resources and legislation, thereby magnifying the 'tempest in a teapot' into the 'arena' of imperial politics. The cultic tendencies and the resultant unity that then forged were the much-needed nexus with Constantinian imperial policy. Deductively, this was incentivised by the capacity for unifying the empire through a united Christianity. Although paradoxically Christianity was characterised by schisms, it aggregately remained networked and unified ideologically (cf. Brent 2009).

\section{Convergence}

Constantinian rule was a convergence of philosophy, ideology and theology with politics (Brent 2009:278-284; Schott 2008:125-127). Constantine's anti-polytheistic polemics were a mockery of the pagan pantheon as chaotic, rather upholding the sanity of Christian monotheism. For example, in Constantine's Oratio ad Sanctorum Coetum 3.3-4 (Schaff 1885c:850), he derisively taunted the order in sacrifice, questioning to whom one should pray first.

Constantine showed himself to be under the influence of second sophistic in his positions at Nicaea regarding logos [word] ideology, a derivate from Origen. The logos ideology taken separately had implications upon imperial divine claims as it cemented Constantine's sole rule amongst the people as divine. The tetrarchy was now a thing of the past; this was a new era. One God represented in his Son would find parallel in One Emperor, and One Empire. This convergence was factored by a process that had preceded the imperial interposition in Christianity.

\section{New model}

The implied hypothesis in this document concerning the formation of the orthodoxy that emerged at the turn of 4th century CE can be adapted into modular form. A review of Christianity's 1st centuries culminating in the involvement of Constantine at Nicaea implies the emergence of an 'ecumenical' orthodoxy. This orthodoxy was conciliar, and bound by an ecclesiastical and political symbiote that then characterised imperial Christianity (Cyprian Epist ad Ant 54.8-10; Hall 2012:432; Schaff 1885b:606-608).

The emergence of the respective imperial Christianity and its orthodoxy against the background of three factors (schism, Hellenism and politics) was riddled by an implied feature that transcended all three phases - that of authority in the Christian movement. Christianity as a factor of the three catalysts emerged with a visible hierarchical leadership throughout the three phases. The three catalysts can be conceptualised as a tripartite model:

1. First stage in Christian self-definition social catalyst - a schismatic element (the Christian-Jewish separation). 
2. Second stage of Christian self-definition syncretism Hellenism (characterised by the second sophistic, Gnosticism).

3. Third stage of Christian self-definition political-imperial interposition (imperial-ecclesiastical symbiote - imperial plus ecumenical polity).

The preceding layout is an implied perception of the trajectory that oversaw the emergence of a conciliar orthodoxy as at Nicaea. This conceives the deduction regarding the influential councils that defined orthodoxy and catholicity in the 4th century CE going forward. Notably, the involvement of the emperor in ecclesiastical polities buttressed the council edicts or resolutions with an imperial endorsement. As argued in the secondary literature, the monarchical episcopate as traceable in Ignatius and Cyprian is an undisputable feature of 2nd-century CE Christianity going forward (Barnes 2011; Brent 2009; Van Dam 2012).

The ascription of a degree of significance to the dominancy of the episcopate as the synthesising catalyst is, however, a notable discussion regarding Christian self-definition. This reviews the emergent orthodoxy in the 4th century as imperial and episcopal, a synthesis of ecclesiastical and imperial polities adjacent to multi-syncretism in the form of Hellenism and paganism. This conceived trajectory is traceable to the ecclesiastical imperial polities consequent in the post-Constantinian era and also in geographically diverse territories. The perceived trajectory found culmination in the medieval era in a form of absolute power by the episcopate.

The synthesis of the respective catalysts in the formation of an orthodoxy and inadvertently entrenchment of a religiouspolitical hierarchy poses a modular theory. As a heuristic tool of investigation, the analysis of the Jewish-Christian schism, Hellenism and imperial intervention can be implied and derived. When taken generically, the catalysts can be taken as representing social or cultural-ethnic dynamics (schism), culturally induced religious syncretism (Hellenism) and politics (ecclesiastical polities and imperial intervention).

The generic version of the hypothesis can be implied upon the investigation by reviewing and inferring it from an era preceding that of the imperial establishment of orthodoxy. Alternatively, the generic version of the hypothesis can be derived from the investigation by inferring it upon a latter period. In an implied use of the hypothesis, reflections can be deduced from second temple Judaism and its sectarian strata.

\section{Deductions from Judaism: Sociological modular approach}

When adapted to the establishments of Piovanelli's socioreligious analysis of second temple sectarianism, there is a substantiation of the theory (Piovanelli 2007:157). Piovanelli places scholars on Judaic research scholars on a trajectory of revisionism, and also mentions Saldarini (1988), Cohen (1991), Nickelsburg (2003) and Davies (2007).
These scholars contributed to the comprehension of the Jewish matrix as a new ideological-sociological nexus derived from Maccabean politics. When placed on a trajectory, these works evidently trace the advancement of anthropological, cross-cultural and social-scientific models in reflections on religious history (Piovanelli 2007:156). This development regarding the use of social theory in congruence with the implied reference of the theory upon ecumenical orthodoxy redefines the Jewish social matrix.

Piovanelli noted, however, the fallacy that derives from an over-theorisation of socio-religious dynamics as in the models of Weber (1930), yet despite despite the irrelevance of a mathematical formula in reviewing sociocultural dynamics, a flexible and heuristic model would be functional (Piovanelli 2007:157).

Implementation of the above application of social theory upon second temple sectarianism is done in light of Meissner (2000), who emphasised the cultic nature of Christian selfdefinition. This conceives several insights.

Despite the generational margin between the investigated period (early Christianity) and the second temple, deductions are inferred that facilitate a review of social or ethnic dynamics, syncretism and politics. This is derived from a review of the emergence of Pharisaic eminence and second temple theology. The rise of this second temple elitist aristocracy concurrently with resultant sects poses a parallel significance to the heretical orthodoxy sectarianism and episcopal hierarchy in early Christianity. Arguably, politics as a catalyst is a common feature in the narratives of both eras considering the rise of ecclesiastical authority and orthodoxy against the political interactions within the Jewish second temple era.

The second temple era poses as a complex matrix given the background of Hellenistic and syncretistic post-exilic Judaism that was then exposed to Roman occupation (Klawans 2012:140-141). Revisionist deductions of Josephus' conceptualisation of second temple theology imply a battle against the Torah and tradition versus innovation. Josephus projects a growing, influential Pharisaic establishment against the unpopular untraditional Sadducees (Josephus' Wars of the Jews 2.8.14, O'Bannon 2016:1222). The situation posed a symbiotic theological-political skirmish.

Josephus implied the Sadducees as a form of weak link in the Sanhedrin regarding the resistance because he portrayed a passive Sanhedrin tolerant of offenses by Agrippa and the Romans (Wars 2.16.2, O'Bannon 2016:1249). The deduction is premised by the characterisation of the Sadducees as a form of aristocracy bent on power and detached from tradition. On the contrary, the Pharisees were portrayed as masterminding an ideology of revolt for the assertion of Jewish liberty (Antiquities 18.1.6, O'Bannon 2016:956). The Pharisees postured an aura of heroism that derived from patriotic resistance and the criticism of Herod. This selfidentification by the Pharisees implied a rapport with all sects that idealised revolutionary and transformational elements against the established order (Piovanelli 2007:160). 


\section{Cultic self-definition and the rise of Pharisees}

Josephus portrayed a popular Pharisaic movement that emerged alongside a temple ideology characterised by national and theological unity (Klawans 2012:173). Deductively, the Sadducees, though a political aristocracy, also had a sociocultural significance in the theory given their syncretism with Hellenism. Explicitly, they (Sadducees) resonated with a form of Hellenistic apologetic; this is distinguishable in the Zadokite Judaism from which the Sadducees derived (Boccaccini 2002:123).

The New Testament substantiates the historicity of the Pharisaic authority as endemic. Klawans (2012:174) refers to this dynamism as 'reflections of Pharisaic popularity in the eventual predominance of Rabbinic Judaism'. The popularity of the Pharisees can be attributed to their reformist agenda that implied an emphasis on custom. This religious reform posture composite to political resistance ideology forged socio-political ties between them and other revolutionary sects (Ant Jud 17.2.4-3.1; O'Bannon 2016:911-913) (cf. Wilson 1970). The Pharisees therefore represented a national unity that was characterised by a rejection of external influences. This redefines the second temple era as a narrative of a cultic or self-defining process.

Compositely, the consolidation of Pharisaic influence that was buttressed by the Sadducees (aristocracy)-Pharisaic Sanhedrin alliance and the cosy attachment between the Sadducees with Rome all imply a complicated narrative of political enculturation and definition.

In comparison to the early Christianity's political selfdefinition that was overwhelmed by a euphoric endearment to imperial interposition in the 4th century, the Jewish religious political matrix posed a complex scenario. The narrative regarding Jewish religious-political definition is one of give and take. There seems to have been a counterbalance between hostilities and compromise by perceivably an idealistic political institution.

There is a resemblance with formative episcopal polities in early imperial Christianity. The orthodoxy that emerged as a result of these formative catalysts in rabbinical Judaism was Pharisaic. Similarly, ecumenical orthodoxy reflected episcopal philosophy and theology. Perceptively, the second temple era and its political dynamics when exposed to the model deductively, implies that syncretism and politics evidently shaped Jewish orthodoxy as much as they would shape Christianity.

\section{Derived episcopal polity and imperial conciliar orthodoxy}

The significance of councils corresponded with the eminence of the episcopate. The importance of bishops as functionaries within the environment from which emerged a political and syncretised conciliar orthodoxy has implications for ecclesiastical politics. The initiative for councils can definitely be attributed to imperial interposition as a measure to further the pax [peace] and homonoia [harmony] of the church and empire, respectively (Irenaeus Against Heresies 4.30.1.3, Schaff 1885a:841-843; Brent 2007:32; Ignatius Letter to Smyrna 8.1, Schaff 1885a:147).

Notably, the peace and unity that were inevitable in a prosperous Rome had much to do with ecclesiastical polities since the new religion Christianity, was empire-wide. That Irenaeus could praise the pax as being favourable to Christendom implies the relative peace that was mutual in the Roman political and religious domain (Irenaeus Against Heresies 4.30.1.3, Schaff 1885a:841-843). The Christians were at peace and not persecuted if the benevolence of traditional Roman gods was not doubted. With the entrance of Constantine, the church 's peaceful prosperity would be key to the magnificence of the empire (Eusebius VC 4.24; Schaff 1885c:826). Therefore, the interconnected nature of these dynamics implied an enforcement and empowerment of an institution that, prior to Constantine, was exclusively ecclesiastical in its authority.

Emphatic in Ignatius was the eminence of the Bishop and and how subordination to his authority as religious practice, which inadvertently empowered the episcopate (Ignatius Letter to Smyrna 8.1, Schaff 1885a:147).

The precedent nature of the episcopal hierarchy that stems from its origin prior to the rise of imperial Christianity was also a definitive dynamic. The accretion of ecclesiastical politics in the form of clerical polities was a continuation and metamorphosis of intrinsically Christian dynamics. The episcopal polities created the scope for imperial interposition to work within. The notion of imperial Christianity is redefined as imperial orthodoxy through episcopal extensions.

In Brent's words, Constantine could, by extension, use bishops but could not substitute them for another political instrument (Brent 2009:286). The 325 CE Council of Nicaea was an episcopally induced event under imperial auspices; the ecumenical council poised an emperor entangled within ecclesiastical polities riddled with philosophical ideology and strife creating hierarchical feuds (Barnes 2011:140).

The latter dynamic political entrenchment of bishops in the post-Constantinian era is not at all surprising when placing the preceding matters in perspective. Bishops went on to supersede the influence of the emperor in ecclesiastical and secular affairs in certain scenarios. Arguably, imperial Christianity and its conciliar orthodoxy salvaged a political import as it signalled the dawn of an empowered episcopal polity.

The decline of Western Rome evidenced the emergence of ecclesiastical-clerical power and ultimately the rise of the Carolingian monarchy against the backdrop of a waning imperial complex, affirmed it as a brainchild of ecclesiastical manoeuvring and consolidation of power. 


\section{Frankish Christian monarchy - Episcopal imperial revival}

The growing influence of episcopal polities became definitive of imperial dynamics, such as the Carolingian dynasty. The emergence of the Carolingian dynasty denotes it as an institute conjured from a merger of ecclesiastical and national polities. The conciliar resolutions or canons once empowered by imperial legislation implied that clerics further became an elite ecclesiastical-social clique as evidenced by the authority wielded by the councils convened (Moore 2011:23).

A notable factor from which the eminence of ecclesiastical leadership derived was the waning imperial institute. Inevitably, Bishops under Constantine had become somewhat appendages to imperial governance and with some having priviledged backgrounds assumed aristocratic power. Clerics brokered truces with barbaric tribes in place of the aristocracy (Moore 2011:23).

The coherence between the episcopate and Roman aristocracy implied that the bishopric had somewhat metamorphised into a senatorial or prefecture function. The Arles Councils, the first of the Gallic conciliar tradition, was a show of their imperially induced legal authority in the form of episcopalis audientia [courts presided over by bishops]. The intransigent and dynamic nature of the episcopate was evidenced by its capacity to withstand political and cultural turbulence whilst retaining aristocratic and legal functions. The decline of Rome, civil wars and barbaric incursions overpassed the episcopal institution (Moore 2011:23).

Syncretistic and ecclesiastical-imperial political elements by determining a form of orthodox governance implied that the future of European monarchies was to be influenced extensively by ecclesiastical dynamics. The preceding is attributable to the intricacy of the episcopate as an institution (Moore 2011):

We can view the councils as mirrors partially clouded by time, but reflecting the steady development of the episcopate as an aristocratic body engaged in the wholesale transfer of Roman cultural ideals to the church and the emerging governance by bishops over their regional communities. (p. 55)

This establishes how the cultic process oversaw the emerging ecclesiastical superstructure of an entity both political and ecclesiastical in the form of the episcopate. Even in narratives where bishops are portrayed as mere extended imperial functionaries, arguably their outgrowth and autonomy in the political sphere can be traced. The development of the episcopacy can be reviewed as analogous to time and the decline of imperial magnanimity. The preceding entrenches the base from which an episcopal power spiral would emerge to guarantee episcopal significance and relevance as political players in the pre-medieval and, mostly, medieval era.

The audacity of Hilary of Poitiers in penning a polemic against the Arian Constantius II in defence of Nicene orthodoxy and its adherents implies that the bishops could boldly dare imperial flaw (Liber Contra Constantium, Wickham
1997:14). Notably, the tension between the Byzantine emperor and certain parts of Christendom characteristically became nationalistic. The episcopate in Gaul region by associating with Hilary now adopted a stance as the Gallicani episcopi [Gallican bishops], thereby implying socio-ethnic enculturation. This would have political implications upon Byzantine which sought the retainment of Constantinian eminence, as it was evident episcopal polities maintained an evolutionistic continuum as a political-religious outfit.

Kings became pawns in ecclesiastical schemes. The Roman See Pope Stephen saw interest in the hostilities between the Frankish King Pippin and the Byzantine emperor. The turf against orthodoxies now embroiled kings (Moore 2011:244). As an embodiment of theocratic rule, the Carolingian dynasty was an episcopal brainchild (Moore 2011:244). Perceivably in the post-Constantinian era, the ecclesiastical establishment had the capacity to develop a politico-religious orthodox establishment. This, arguably, established the active role of clerics in pre-medieval and medieval monarchical dynamics.

The Gallican episcopate was definitive of the European political terrain post-Byzantine. 'Having participated in the Carolingian coup d'état, the bishops found their status heightened' (Moore 2011:244).

Consequentially, there was a mutually beneficial union between the dynasty and bishopric mainly derived from mutual interest. The consolidation of the kingdom appealed to monarchical pomp whilst corresponding re-engagement with churches in Northern Italy was an ecclesiastical advantage. That the Frankish ecumenical influence could extend to east of the Mediterranean implied the strengthening of a nationalistic ecumenical order (Moore 2011:245).

The intricacy of ecclesiastical and monarchical polities became definitive of the post-Constantinian era of politicoreligious orthodoxy. The episcopate incited conquest and wars, which kings would pursue at the benediction of the clergy. This became a recurrent feature in the medieval era. Charlemagne represented an attempt to reincarnate imperial Christianity by clerics (Moore 2011:246). This interestingly poses a possibility that the Constantinian definition of ecclesiastical-imperial politics reshaped the episcopate.

As a result of the respective effect, it was inevitable that there would be an establishment composite of ecclesiastical and secular power.

The emergent scenario implied an intricacy of conciliar politics. From the emergent imperial clerical conciliar orthodoxy there stemmed a phenomenon of politicalepiscopal authority. Although the episcopal hierarchy and authority cannot be attributed to Constantinian politics, the contact made between the two forged a phenomenon that transcended their respective epochs (cf. Brent 2009). This implies ecclesiastical polities as an autonomous momentum absorbed into imperial stratagems. 


\section{Synthesis: Figure 1}

In an attempt to synthesise the discussion regarding the implied and derived study of politics, syncretism and socioethnic dynamics in orthodoxy, a model was formulated. The diagram explains the model as a derivate from second temple theology. Secondly, it emphasises the formative nature of the catalysts in the emergence of the imperial orthodoxy establishment. Lastly, it highlights the implications of the model on Frankish Christianity as an evident progression of the self-definitive process in Christianity. Figure 1 is derived from a previous research done by author, Rukuni (Rukuni 2018:156).

Coherent to the study emphasising the significance of formative catalysts to an imperial orthodoxy, the diagram is a synthesis of the investigation's deductions in the formulation of a model for reviewing Christian eras perceivably factored by formative catalysts.

The tripartite categorisation is placed in comparison of the three catalysts - or their equivalents - being studied. This is in relation to how they shaped the Christianity or religion so as to forge an orthodoxy. The respective eras are connected to the argument for either its implicative (implications upon the era being studied) or deductive role (implications from the era being studied).

The first category is for the Jewish Second Temple era from which emanated second temple orthodoxy. The parallelism of interacting factors is derived from the preceding era in history basing on the cultic and acculturative nature of respective elements common to both the second temple and Christianity. Generically, the Greek and consecutively Roman occupation analogous to sectarianism represent the political feature.

Hellenism and schismatic dynamics of sectarianism imply socio-ethnic enculturation. The complexities of acculturation and the emergence of Pharisaic rabbinic orthodoxy were also socio-ethnically complicit. The establishment of the religious-political outfit of the Pharisees evidences a convergence of the three factors.

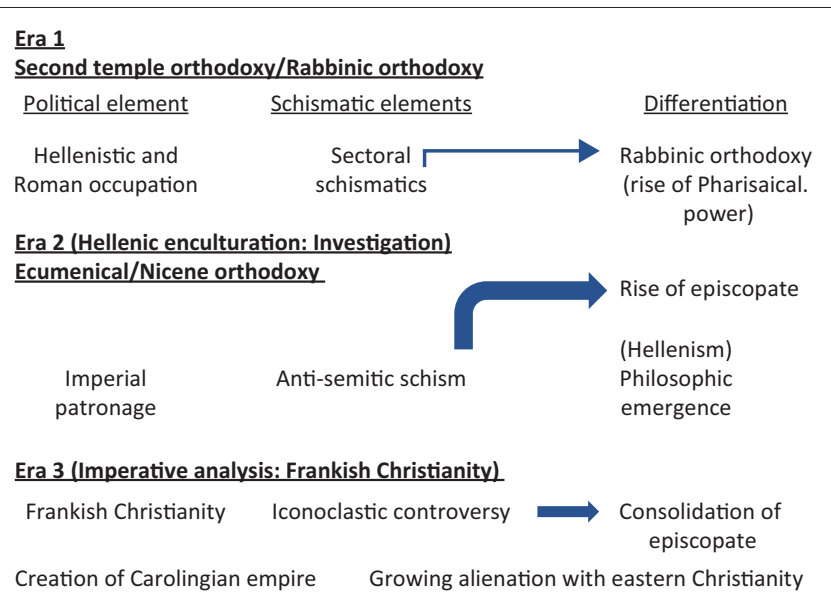

FIGURE 1: Socio-political matrix of orthodoxy.
The second category is the era preceding the Nicene Council. This is conceptualised as an investigation of the JewishChristian schism, Hellenic enculturative syncretism and Constantinian imperial interposition in Christendom. From the preceding investigation, an outgrowth is highlighted in the form of the episcopate.

The third and final category reviewed proceeded from the decline of Constantinian aura and western imperial Rome. This was the emergence of the Carolingian dynasty and correspondingly Frankish Christianity. The manner in which the episcopate is on record in masterminding political events at this juncture is background to the politico-religious outfit. The socio-ethnic dynamics in this case derived from the schismatic turbulence of the iconoclastic controversy. The scenario consequent from the orthodox-heretical strata of the iconoclastic controversy was reflective of the emergent rift between eastern and western Christianity. Consequently, the consolidation of a political episcopacy was a common result.

\section{Patriotic orthodoxy: The African Donatist Church (anti-thetical argument for model)}

As a prelude to Nicaea (first ecumenical council), the Donatist controversy and the Arles synod imply a narrative of culturalethnic resurgence that resisted the imperial orthodox factored by the emperor. This served to establish the incapacity of the religious-political establishment to integrate a universal orthodoxy without the foundational socio-ethnic acculturation. This furthers the case for the multiple factors influencing the emergent orthodoxy.

The African church, particularly Carthage, diverged from the universal unity sought by imperial orthodox establishment of the Emperor Constantine (Roldanus 2006:40; Tilley 2012:388). This brings to view the existence of localised orthodoxy. The obstinacy of the Donatists/Numidians perceivably stemmed from an insistence upon local practises. The capacity of the Donatist movement to endure and transcend its era of origin undiluted by imperial interposition, whilst in opposition of the established episcopal order implies the feasibility of their cultural-ethnic cause. The Donatist resistance resonates with persecution era practices.

Given the vagueness of Jewish Christianity and elements of it as remnant in North Africa (Oden 2011:76-85), the Donatist scenario proposes an alternative model and theory based on the significance of socio-ethnic cultural dynamics in the definition of Christianity (cf. Tilley 2012:384).

The Punic anti-Latin sentiment and Berber relations served to complicate the political-ethnic matrix characterised by antiRoman sentiments. Composite to the scenario was the marginal influence of imperial Rome in certain regions of Carthage. This implied that the confluence of the three factors was inevitable to guarantee meaningful definitive implications upon Christian orthodoxy. 
Parallel to the Donatist dynamic, Ethiopian Christianity was characterised by a complex matrix of sociocultural influences. The Christianity was intrinsically Judaic and intransigently resisted exotic attempts at syncretism such as Islam and Catholicism (Boavida, Pennec \& Ramos 2011:359, Isaac 2013:38-39). Significantly, Ethiopian Christianity, just as Donatism, was ideologised. Ethiopianism, the incarnated conceptualisation of Ethiopian resistance, incited African Nationalism (Kalu 2006:586).

As a case substantiating the incapacity of a sole factor in conjuring up a universal practice amongst Christians, a review of the intransigence of Donatism has implications. The separation of the Christendom geographically was a veil for an underlying challenge at acculturation. Ecumenical councils, such as Arles synod of CE 314, were an attempt at unifying a religious society separated both geographically and culturally (Lyman 2012:304). This probably brewed an environment that saw the growth of a local orthodoxy that rivalled the emergent imperial-ecclesiastical establishment and its political episcopate.

\section{Lyman (2012) reiterates the idea that:}

Appeals to antiquity and the apostolic succession of the episcopacy, as well as pilgrimage, shrines and liturgical traditions, strengthened not only the larger religion of Christianity, but also the local incarnation of it ... Donatist controversy and the Miaphysites in the East reflected the strength of local ... tradition not easily dislodged by councils or imperial edicts ... but rather councils cemented these local practices intransigently. (p. 304)

The exclusive nature of Donatist Christianity is attributable to Cyprian and Tertullian's ideologies. This is mainly because of the organic nature of their writings to their African environment, its tradition and dually their political implications. Cyprian, though a renowned champion for a Catholic orthodoxy as emphatic in his writings (Unit Eccl 10-14; Schaff 1885b:744-746), was anti-imperial as resonate with the then pervading environment. The clerical hierarchy to which the merger with imperial polities during the Constantinian turn has been attributed was created to withstand the imperial persecution during the reign of tyrants, such as Decius (Brent 2009).

The framework from which African ideology would derive would pose a problem with regard to imperial relations, a further entrenched challenge to the political enculturation of imperial orthodoxy. This was evident in the caste system that defined African Christianity, where past compromise and contact with persecutors determined one's moral acceptance within the institution (Tilley 2012:389). This implied that a cosy relationship with the emperor was not going to be easily accepted as orthodox.

It seems a firm belief in persecution defined the very essence of the Donatist movement. The intransigence against the traditores [compromisers] and lapsi [fallen] coupled with the denial of imperial imposition characterised the
Donatist movement. These deductions already establish the complexity of political and socio-ethnic enculturation in North African Christianity. Drawing from the preceding reference to Judaic influences, and linguistic detachment of regions in Carthage, poses an alternate theory.

This was Christianity not as affected by the Jewish-Christian schism, and not as Hellenised and ultimately resistant to the Constantinian imperial interposition. The militancy of the resistance as substantiated in the riots that broke out in 317 CE implies that this was an intransigent movement - an autonomous institute in the midst of the then emergent orthodoxy (Leithart 2010:160). Narratives regarding the riots paint a shade of heroism by the Donatists as unswervingly loyal to the cause for a pure faith, in which they had been susceptible to the barbarism of an evil alliance between the lapsed Caecilianus and Roman soldiers (Barnes 2010:123, 153).

Building the case for a patriotic orthodoxy that was region specific, Augustine as a representative of African Christian political ideology can be seen not to have been entirely against the Donatists. References to the Donatists by Augustine as schismatics versus labelling them as heretical imply a common African cause (Lyman 2012:305). In affirmation of Augustine's acceptance of the Donatists as fellow believers is the appeal he made on their behalf to the proconsul of Africa, Apringius (Augustine to Apringius and Marcellinus Ep 133.2 [eds.] Atkins \& Dorado 2007:62). The trouble with Donatists further establishes Roldanus's (2006:6) theory regarding the definitive significance of cultural elements in the formation of Christianity. This is because the intransigence of the Donatists was based on the practice of traditional Christianity versus an imposed orthodoxy that they deemed as Roman.

Perceivably, there seems to have been a correlation between post-persecution reactions and intransigent schisms in Africa. These schismatic parties were possibly a reincarnation of Novatianism and Donatism.

Carthage, the city from which these two ideologies and the controversies emanated, posed as an intricate case of enculturation. Cyprian, interestingly, buttressed the episcopate, formulating episcopal ideology withstanding Roman persecution and internal schismatics using heathen philosophy sella curialis [the seat representative of the magistrate's geographic domain]. Undoubtedly, the episcopate was an established factor despite the cultural complex of Carthage. A non-tolerance of divergence implied the intransigence of an autonomous establishment that claimed orthodoxy (Epistulae 27.3.1; Schaff 1885b:544; Brent 2009:271).

\section{Conclusion}

The era preceding the 4th-century CE Christianity was definitive. When reviewed from the Jewish-Christian schism as an inceptive event in the acculturation or contextualisation of Christianity (cf. Roldanus 2006), a social trajectory can be 
deciphered that ran analogous to consecutive historical dynamics. This establishes a case for a social model of reviewing the history of Christianity. Extendedly, this facilitates the analysis of other religions.

Generically, social factors such as socio-ethnic dynamics, enculturation and politics can be deduced as catalysts in the self-definition of religion. The emergent clerical-episcopal leadership in Christianity was consequent of the proposed model. In a parallel review, the ascension of the Pharisees to national religious-political significance and their capacity to consolidate post-temple Judaism derived from the trajectory that was present in the second temple era.

Enculturation and schismatics establish certain groups, thus harmonizing with Bauer's (1971) theory of orthodoxy and heresy in early Christianity (cf. Decker 2015). However, the entrenchment of the respective groups in this research is attributed to the selfdefinitive process rather. The greater substantiation of the theory or model derives from the perceived continuum as evident in further development of a political episcopacy.

Insubordination and the intransigent nature of the episcopal establishment further affirms the precedence of ecclesiastical polity as an earlier dynamism to imperial political interposition. The other substantiation for the preceding argument was in the post-Constantinian or Byzantine era that characterised Frankish Christianity and the foundation of the Carolingian dynasty.

Finally, enculturation precedes all other social processes in the success of a universal orthodoxy. The intricacy of African Christianity socio-ethnic complex is evidenced. Correspondingly, the Donatist case though paramount implies a recurrence of definitive schismatics in African Christianity that stemmed from an insistence on local tradition or rather resistance to perceived external imposition. This implies a synergy of the three catalysts considered when they are placed in parenthesis. The schism, Hellenism and politics represent dynamics inevitable in the formative process of early Christianity. In places not as non-Judaised through the schism, or those not as Hellenised because of resistance to Romanisation, a worthwhile example being excerpts from Carthage, the emergent orthodoxy that had been a common feature of 4 th-century Christianity would not fit.

Ultimately, this implies a modular tool through which African Christianity can be reviewed, as a detached feature from Roman imperial orthodoxy.

\section{Acknowledgements Competing interests}

The authore have declared that no competing interests exist.

\section{Authors' contributions}

All authors contributed equally to this work.

\section{Ethical consideration}

This article followed all ethical standards for carrying out research without direct contact with human or animal subjects.

\section{Funding information}

This research received no specific grant from any funding agency in the public, commercial or not-for-profit sectors.

\section{Data availability statement}

Data sharing is not applicable to this article as no new data were created or analysed in this study.

\section{Disclaimer}

The views and opinions expressed in this article are those of the authors and do not necessarily reflect the official policy or position of any affiliated agency of the authors.

\section{References}

Atkins, E.M. \& Dorado, R.J. (eds.), 2001, Augustine political writings, Cambridge University Press, New York.

Barnes, T.D., 2010, Early Christian hagiography and Roman history, Mohr Siebeck, Tübingen.

Barnes, T.D., 2011, Constantine. Dynasty, religion and power in the Late Roman Empire, Wiley-Blackwell, Chichester.

Bauer, W., 1971, Orthodoxy and heresy in earliest Christianity, R.A. Kraft \& G. Krode (eds.), 2nd edn., Fortress, Philadelphia, PA.

Boavida, I., Pennec, H. \& Ramos, M.J. (eds.), 2011, Pedro Paez's history of Ethiopia 1662, 2 vols., Ashgate/The Hakluyt Society, London.

Boccaccini, G., 2002, Roots of Rabbinic Judaism: An intellectual history from Ezekiel to Daniel, Eerdmans, Grand Rapids, MI.

Boyarin, D., 2010, 'Judaism as a free church: Footnotes to John Howard Yoder's The Jewish-Christian Schism Revisited', in P. Dula \& C.K. Huebner (eds.), The New Yoder, pp. 1-17, Cascade Books, OR.

Brent, A., 2007, Ignatius of Antioch: A martyr bishop and the origin of episcopacy, T \& T Clark, New York.

Brent, A., 2009, A political history of Early Christianity, T \& T Clark, New York.

Cohen, J., 1991, Essential papers on Judaism and Christianity in conflict: From Late Antiquity to the Reformation, New York University Press, New York.

Danto, E.A., 2008, Historical research, Oxford Scholarship Online, viewed 12 January 2018, from http://www.oxfordscholarship.com/view/10.1093/acprof: oso/9780195333060.001.0001/acprof-9780195333060

Davies, P.R., 2007, 'Sect formation in Early Judaism', in D.J. Chalcraft (ed.), Sectarianism in Early Judaism: Sociological advances, pp. 133-155, Equinox, London.

Decker, R.J., 2015, 'The Bauer thesis: An overview', in PA. Hartog (ed.), Orthodoxy and heresy in Early Christian contexts: Reconsidering the Bauer thesis, pp. 6-34, Pickwick Publications, Eugene, OR.

Drodge, A.J., 2012, 'Self-definition vis-à-vis the Greco-Roman World', in M.M. Mitchell \& F.M. Young (eds.), The Cambridge history of Christianity: Origins to Constantine, pp. 230-245, Cambridge University Press, New York.

Gamble, H.Y., 2012, 'Marcion and the "canon"', in M.M. Mitchell \& F.M. (eds.), The Cambridge history of Christianity: Origins to Constantine, pp. 195-213, Cambridge University Press, New York.

Grabbe, L.L., 2007, 'When is a sect a sect - or not?', in D.J. Chalcraft (ed.), Sectarianism in Early Judaism: Sociological advances, pp. 114-132, Equinox, London.

Hall, S.G., 2012, 'Institutions in the pre-Constantinian ecclesia', in M.M. Mitchell \& F.M. Young (eds.), The Cambridge history of Christianity: Origins to Constantine, pp. 415-433, Cambridge University Press, New York.

Isaac, E., 2013, The Ethiopian Orthodox Tawahido Church, The Red Sea Press, Trenton, NJ.

Kalu, O.U., 2006, 'Ethiopianism and the roots of modern African Christianity', in S. Gilley \& B. Stanley (eds.), The Cambridge History of Christianity: Vol. 8: World Christianities c. 1815-c. 1914, pp. 576-592, Cambridge University Press, Cambridge.

Klawans, J., 2012, Josephus and the theologies of Ancient Judaism, Oxford, New York.

Leithart, P.J., 2010, Defending Constantine: The twilight of an empire and the dawn of Christendom, InterVarsity Press, Downers Grove, IL. 
Lyman, J.R., 2012, 'Heresiology: The invention of "heresy" and "schism"', in A. Casiday \& F.W. Norris (eds.), The Cambridge history of Christianity: Constantine to c. 600, pp. 296-317, Cambridge University Press, New York.

Markschies, C., 2003, Gnosis: An introduction, transl. J. Bowden, T \& T Clark, New York.

Meissner, W.W., 2000, The cultic origins of Christianity: The dynamics of religious development, The Liturgical Press, Collegeville, PA.

Moore, M.E., 2011, A sacred kingdom: Bishops and the rise of Frankish Kingship, 300-850, vol. 8, The Catholic University of America Press, Washington DC.

Nickelsburg, G.W.E., 2003, Ancient Judaism and Christian origins: Diversity, continuity and transformation, Fortress Press, Minneapolis, MN.

O'Bannon, K., 2016, Josephus: The complete works, Christian Classics Ethereal Library, Grand Rapids, MI.

Oden, T.C., 2011, The African memory of Mark: Reassessing early church tradition, IVP Academic, Downers Grove, IL.

Piovanelli, P., 2007, 'Was there sectarian behavior before the flourishing of Jewish sects? A long-term approach to the history and sociology of Second Temple Sectarianism', in D.J. Chalcraft (ed.), Sectarianism in Early Judaism: Sociological advances, pp. 156-179, Equinox, London.

Roldanus, J., 2006, The church in the age of Constantine: The theological challenges, Routledge, London.

Rukuni, R., 2018, The Schism, Hellenism and Politics: A review of the emergence of Ecumenical Orthodoxy AD 100-400. UNISA, Pretoria.

Saldarini, A.J., 1988, Pharisees, scribes, and sadducees in Palestinian society: $A$ sociological approach, Michael Glazier, Wilmington, DE.
Schaff, P. (ed.), 1885a, Ante-Nicene fathers, Vol. 1: The Apostolic fathers with Justin Martyr and Irenaeus, Christian Classics Ethereal Library, Grand Rapids, MI.

Schaff, P. (ed.), 1885b, Ante-Nicene fathers, Vol. 5: The fathers of the third century: Hippolytus; Cyprian; Caius; Novatian; Appendix, Christian Classics Ethereal Library, Grand Rapids, MI.

Schaff, P. (ed.), 1885c, Nicene and Post-Nicene fathers, Series 2, Vol. 1: Eusebius Pamphilius: Church history, life of Constantine, oration in praise of Constantine, Christian Classics Ethereal Library, Grand Rapids, MI.

Schott, J.M., 2008, Christianity, empire, and the making of religion in Late Antiquity, University of Pennsylvania Press, Philadelphia, PA.

Tilley, M.A., 2012, 'North Africa', in M.M. Mitchell \& F.M. Young (eds.), The Cambridge history of Christianity: Origins to Constantine, pp. 485-503, Cambridge University Press, New York.

Van Dam, R., 2011, Remembering Constantine at the Milvian Bridge, Cambridge University Press, New York.

Van Dam, R., 2012, 'Bishops and society', in A. Casiday \& F.W. Norris (eds.), The Cambridge history of Christianity: Constantine to c. 600, pp. 343-367, Cambridge University Press, New York.

Weber, M., 1930, The Protestant ethic and the spirit of capitalism, S. Kalberg (ed.), Rotledge, Abingdon (this edition 2013).

Wickham, L.R., 1997, Hilary of Poitiers, conflicts of conscience and law in the fourthcentury church, Liverpool University Press, Liverpool.

Wilson, B.R., 1970, Religious sects: A sociological study, McGraw-Hill, New York. 